\title{
Seroprevalence and Associated Risk Factors of Canine Leptospira and Brucella Species Infection in West Shewa Zone, Central Ethiopia
}

This article was published in the following Dove Press journal: Veterinary Medicine: Research and Reports

\author{
Lencho Megersa Marami iD \\ Endrias Zewdu \\ Gebremedhin (iD ${ }^{2}$ \\ Edilu Jorga Sarba (iD) ${ }^{2}$ \\ Getachew Kebebew Tola ${ }^{2}$ \\ Solomon Shiferaw Endalew \\ Asamenew Tesfaye Melkamsew ${ }^{3}$ \\ Vincenzo Di Marco Lo Presti ${ }^{4}$ \\ Maria Vitale ${ }^{4}$

\begin{abstract}
'Ambo University, College of Agriculture and Veterinary Sciences, Department of Veterinary Laboratory Technology, Ambo, Oromia, Ethiopia; ${ }^{2}$ Ambo University, College of Agriculture and Veterinary Sciences, Department of Veterinary Sciences, Ambo, Oromia, Ethiopia; ${ }^{3}$ National Animal Health Diagnostic and Investigation Center, Department of Immunology, Sebeta, Oromia, Ethiopia; ${ }^{4}$ Istituto Zooprofilattico Sperimentale of Sicily, Laboratory of Genetics of
\end{abstract} \\ Microorganisms, Palermo, Italy
}

Purpose: Canine leptospirosis and brucellosis are significant zoonotic gram-negative bacterial diseases that affect humans and animal species. This study was aimed to estimate the seroprevalence and assess associated risk factors of canine Leptospira and Brucella species infections in Ambo, Bako, and Gojo Towns, West Shewa Zone, Ethiopia.

Methods: A total of 385 serum samples were collected from randomly selected dogs. Antibodies against Brucella and Leptospira species infection were tested using the EnzymeLinked immunosorbent Assay technique (ELISA). A structured questionnaire survey was administered to each dog-owning household to gather information on potential risk factors. The association between independent and outcome variables was analyzed using the Chi-square test followed by univariable, and multivariable logistic regression analyses.

Results: The overall seroprevalence of Brucella and Leptospira species infections were found to be $15.06 \%$ (95\% confidence interval (ci): $11.64-19.04 \%$ ) and $4.16 \%$ (95\% ci: $2.39-6.67 \%$ ), respectively. Multivariable logistic regression analysis showed that the town was the significant risk factor of Brucella species infection seropositivity. Accordingly, dogs found in Gojo ((odds ratio (OR)): $17.72 \mathrm{CI}$ : 1.17-117.54, $\mathrm{p}=0.036$ ) and Bako (OR: 7.99, 95\% CI: 0.96-66.37), $\mathrm{p}=0.054$ towns were more at risk to be infected with Brucella species than dogs living in Ambo. Conclusion: The seroprevalence of Leptospira and Brucella species infections in dogs of the West Shewa Zone was high and moderate, respectively, suggesting the possible transmission of the disease between dogs and other animals. These infections might be an underrecognized threat to public health and animal welfare. Further research on the identification of the serovars of Leptospira and biotypes of Brucella circulating in dogs is encouraged. Finally, knowledge of the comprehensive epidemiology of these diseases is an invaluable input for veterinarians, healthcare professionals, and policy-makers to avoid or manage canine leptospirosis and brucellosis.

Keywords: canine, Brucella, Ethiopia, Leptospira, risk factor, seroprevalence

\section{Introduction}

The pathogenic bacteria, Leptospira and Brucella species cause leptospirosis and brucellosis respectively in many species of animals including cattle, sheep, camels, buffaloes, dogs, and horses around the globe. Leptospirosis and brucellosis are substantial causes of abortion in dogs. ${ }^{1}$ In addition to causing economic losses in the dog breeding industry, these infectious diseases also pose a potential risk to human health, especially to dog breeders and children who come into close contact with dogs. 2,3
Correspondence: Endrias Zewdu

Gebremedhin

Ambo University, College of Agriculture and

Veterinary Sciences, Department of

Veterinary Sciences, P.O. BOX 19, Ambo,

Oromia, Ethiopia

Tel +251911894802

Email endrias.zewdu@ambou.edu.et 
Canine leptospirosis is one of the zoonotic bacterial diseases affecting dogs, other animals, and humans globally. ${ }^{4,5}$ According to the report of Costa et al, ${ }^{6}$ every year 1.03 million people become infected, and 58,900 die from leptospirosis. Asia, Latin America, and sub-Saharan Africa have witnessed this high rate of disease and death. The prevalence of leptospirosis is high in tropical and subtropical wetlands, due to the climatic and environmental conditions in these regions that support the presence of Leptospira spp attributes to high temperatures, rainfall, humidity, the presence of infected domestic and wild animals, and the poor drainage of wastes. ${ }^{7,8}$ In Sub-Saharan Africa, the disease is seen as prevalent, knowledge regarding its epidemiology is still lacking in most countries. ${ }^{9}$

Over 200 Leptospira serovars from 17 genospecies have been identified, and they are distinct from each other by geographical distribution, their host of infection, reservoir, and their virulence factors. ${ }^{410}$ Dogs are susceptible to most Leptospira serovars, including Canicola, Iceterohaemorraghiae, Pomona, Grippotyphosa, and other serovars. ${ }^{11,12}$ However, dogs are the main hosts for Canicola and Icterohaemorrhagiae serovars. ${ }^{13}$ Leptospirosis is recognized to cause late-term abortion in any pregnant animal, including people. ${ }^{4}$ In dogs, the common sign of this disease is septicemic, hepatic, and renal infection with a mortality rate of $10-20 \%{ }^{4,14}$

Healthy animals or humans become infected when they come in contact with infected mucous membranes or skin or milk or vaginal fluid. Besides, humans acquire leptospirosis by direct contact with contaminated drinking water or soil. The main disease reservoirs are rodents, but a variety of wild and domestic animals, livestock, and insectivores are considered as reservoirs. Leptospira enters the body of the susceptible animal or human through mucous membranes, conjunctiva, small cuts, abrasions, and possibly wet skin. ${ }^{4}$

Brucellosis is the most common and serious global distributed zoonotic disease. ${ }^{15}$ It is an endemic disease in North and East Africa, including other developing countries, but has not been reported or less recognized. ${ }^{16}$ Globally, an estimated 500,000 new human cases of brucellosis are reported each year. ${ }^{17,18}$

The genus Brucella has 10 known host-specific species and causes brucellosis in various domestic animals and humans. ${ }^{19}$ B. melitensis, B. abortus, B. suis, and B. canis are the most recognized species of Brucella known to cause brucellosis in people. ${ }^{16,18,20,21}$ Human brucellosis causes acute febrile illness (undulant fever) which may progress to a more persistent form and can also produce serious complications in muscle-skeletal, cardiovascular, and central nervous systems. ${ }^{22}$ B. canis causes asymptomatic infection in humans and may last unconfirmed for a prolonged period, and thus the symptoms include headache, recurrent fever, weakness, fatigue, chills, sweats, and weight loss. ${ }^{23-25}$ The zoonotic risk is moderately high in people who handle rearing dogs in kennels and are exposed to reproductive tissues and fluids of infected dogs. However, chasers and proprietors of hunting dogs are at high risk for transmission of brucellosis from wildlife. Occasional transmission of $B$. canis from pet canine to their proprietors has been reported. ${ }^{21,25}$

Brucella canis is one of the intracellular gram-negative bacteria that mainly causes reproductive failure in dogs. The primary sources of brucellosis in dogs are infected with vaginal discharge and urine of male dogs. ${ }^{26,27}$ The disease is mainly transmitted between dogs through genital, oronasal, conjunctiva, and infected placenta. ${ }^{27}$ Lateterm abortions in bitches, epididymitis in males, and infertility in both sexes are the most common symptoms of canine brucellosis. ${ }^{20,27}$ Dogs are also infected by B. abortus, B. suis, and B. melitensis whenever they share a common environment with cattle, sheep, goats, and pigs. $^{26,27}$

There is no recent data on the seroprevalence of leptospirosis of dogs in Ethiopia after the study done by Moch et al. ${ }^{28}$ Similarly, there is no accessible study conducted on the seroprevalence of canine brucellosis in Ethiopia. However, there is a report of Leptospira seroprevalence in humans in $2004^{29}$ and cart horses in $2016 ;^{30}$ and Brucella seroprevalence in cattle in $2011,{ }^{31} 2016,{ }^{32}$ and $2020 .{ }^{33}$ Knowledge about the status of these neglected diseases in dogs might help to design prevention and control strategies that limit the spread of Leptospira and Brucella spp infections to other animals and humans. Therefore, this research aims to estimate the seroprevalence of canine Leptospira and Brucella spp infections and to determine the associated risk factors in Ambo, Bako, and Gojo towns, West Shewa Zone, Oromia, Ethiopia.

\section{Materials and Methods Study Areas}

The study was conducted in Ambo, Bako, and Gojo towns of West Shewa Zone of Oromia Regional State, Ethiopia. Gojo, Ambo, and Bako towns were purposively selected to 
represent highland, midland, and lowland altitudes, respectively.

Ambo is the administrative center of the West Shewa Zone of the Oromia region is $114 \mathrm{Km}$ located west of Addis Ababa. The town has a latitude and longitude of $8^{\circ}$ $59^{\prime} \mathrm{N} 37^{\circ} 51^{\prime} \mathrm{E}$ and an elevation of 2101 meters. The average annual temperature and rainfall are $22^{\circ} \mathrm{C}$ and $900 \mathrm{~mm}$ respectively. According to Central Statistical Agency (CSA), ${ }^{34}$ the total population of Ambo was 48,171, of which 24,634 were males and 23,537 females.

Bako town, the administrative center of the Bako-Tibe district, is located $260 \mathrm{Km}$ West of Addis Ababa. The town has a longitude and latitude of $9^{\circ} 08^{\prime} \mathrm{N} 37^{\circ} 03^{\prime} \mathrm{E}$ with an elevation of 1743 meters. The average annual temperature is $19.7^{\circ} \mathrm{C}$ while the rainfall is $1281 \mathrm{~mm}$. According to the Central Statistical Agency, in 2005 Bako town has an estimated total human population of 18,641, of whom 9370 are men and 9271 women. ${ }^{34}$

Gojo town is the administrative center of Jeldu district located $120 \mathrm{Km}$ West of Addis Ababa. The town has a latitude and longitude of $9.26^{\prime} \mathrm{N} 38.09 \mathrm{E}$ and an elevation of 2905 meters. The mean annual temperature for the town is $20^{\circ} \mathrm{C}$; it receives an annual rainfall of $2500 \mathrm{~mm}$. The human population of Jeldu district is 202,655 of which 102,796 are females and the remaining 99,859 males. $^{34}$ There were no recorded or known data on the dog population in the three towns.

\section{Study Population}

Dogs found in three towns were the study population. Only owned dogs were included and the stray dogs were excluded from the study. These owned dogs were confined to the home or outdoors. Dogs younger than 3 months of age were not included in the study due to the presence of maternal antibodies that exist at an early age. ${ }^{35}$

\section{Study Animals}

Domestic owned dogs (Canis familiaris) found in selected Gotes ("Gote" is a subdivision of Kebele containing 20-30 households and "Kebele" refers to the smallest administrative unit in a district) were sampled during the house-tohouse survey. Dogs in Ethiopia including in the study towns are primarily used for protection and companionship. Dogs are fed with whatever food is available such as household leftovers and animal products. Vaccination of dogs against brucellosis and leptospirosis was not practiced in the study areas.

\section{Study Design}

The cross-sectional study design was conducted from January 2015 to June 2017 to estimate the seroprevalence of Brucella and Leptospira species infections and to determine their associated risk factors in Ambo, Bako, and Gojo towns of West Shewa Zone, Oromia Regional State.

\section{Sample Size and Sampling Technique}

In Ethiopia, no study was previously done on canine leptospirosis and brucellosis seroprevalence. Thus, 8.3\% expected prevalence, ${ }^{28} 5 \%$ desired absolute precision, and a 95\% confidence interval was used to calculate the required sample size. The sample size was calculated based on the Thrusfield ${ }^{36}$ formula. $\mathrm{N}=\mathrm{Z}^{2} \mathrm{P}$ exp $(1-\mathrm{P}$ exp $) / D^{2}$. Where, $Z=1.96, N=$ sample size, $P_{\exp }=$ expected prevalence, and $\mathrm{D}=$ absolute precision. The calculated sample size (117) was inflated 3.2 times to account for clustering of prevalence during multistage sampling. Therefore, 384 was considered as sample size.

There was no information on the number of dogs in the three towns. Therefore, it is estimated that the number of dogs in the towns was evenly distributed. The number of dog owners living in the study towns was also taken into account. A multi-stage sampling procedure was used to choose households for this study. There are three, two, and one Kebeles in Ambo, Bako, and Gojo towns, respectively. From each "Kebeles," four "Gotes" were randomly selected using the list of Gotes in each Kebeles (sampling frame) provided by local administrators. The index household in a Gote was selected using a simple random sampling technique and subsequent households were surveyed door to door. Of the sample size $(\mathrm{n}=385), 169$ samples were collected from Ambo town, 148, and 68 samples were collected from Bako and Gojo towns, respectively.

\section{Sampling and Transportation}

The blood sample was obtained from the dogs' cephalic vein using a $10 \mathrm{~mL}$ plain vacutainer tubing. The blood specimens were then centrifuged at 3000 RPM for at least 10 minutes. The sera were harvested and transported to the Ambo University Veterinary Microbiology Laboratory in labeled sterile cryovials kept in an icebox with ice packs. The serum samples were transported to the National Animal Health Diagnostic Center (NAHDIC) at Sebeta, under the cold chain, and stored at $-20^{\circ} \mathrm{C}$ until serological testing. 


\section{Serological Tests} Leptospira Species

The serological tests were conducted at the National Animal Health and Diagnostic Center (NAHDIC), Sebeta, Ethiopia. Enzyme-linked immunosorbent assay (NovaTec VetLine Leptospira ELISA, Germany) was conducted according to the manufacturer's instruction to screen antibodies against Leptospira species infection. Microtiter strip wells that pre-coated with a Leptospira antigen were used. Firstly, $100 \mu \mathrm{L}$ controls and diluted samples were dispensed into their respective wells. Secondly, the assay was covered by a foil and incubated for 1 -hour $\pm 5 \mathrm{~min}$ at $37 \pm 1^{\circ}$. Thirdly, the content of each well was aspirated and washed three times with $300 \mu \mathrm{L}$ of Washing Solution. Fourthly, $100 \mu \mathrm{L}$ VetLine Leptospira Protein A/G Conjugate was dispensed into all wells except for the blank well. Fifthly, the assay was covered with foil and incubated for $30 \mathrm{~min}$ at room temperature. Again, the contents of each well were aspirated and washed. Next, $100 \mu \mathrm{L}$ Tetramethylbenzidine (TMB) Substrate Solution were dispensed and incubated for 15 minutes at room temperature in the dark. Finally, the reaction was stopped by adding $100 \mu \mathrm{L}$ of stopping solution. Using the ELISA micro-well plate reader, the optical density (OD) value at $450 \mathrm{~nm}$ was recorded and interpreted as the manufacturer's instruction.

\section{Brucella Species}

The commercial test kits of indirect enzyme-linked immunosorbent assay (ID Screen ${ }^{\circledR}$ Brucellosis Serum Indirect Multi-species, ID. Vet, France) designed to detect B. abortus, B. melitensis, and B. suis were used. The wells of the indirect Brucella ELISA kit were coated with Brucella abortus lipopolysaccharide (LPS). The method is performed according to the instructions given by the manufacturer. In brief, after the dilution buffer, negative control, and positive control were added to the wells. According to the instruction given, $10 \mu \mathrm{L}$ serum samples were added to the remaining wells. Then the test was incubated at room temperature for 45 minutes and the contents of the wells were aspirated. Immediately, empty wells were washed three times by $300 \mu \mathrm{L}$ of the wash solution. Next, $100 \mu \mathrm{L} 1 \mathrm{x}$ conjugate was added to each well and incubated at room temperature for 30 minutes. Again, it was washed three times by $300 \mu \mathrm{L}$ of the wash solution. Later, $100 \mu \mathrm{L}$ of the substrate was added to each well and incubated at $25{ }^{\circ} \mathrm{C}$ for 15 minutes in the dark. Finally, the reaction was stopped by adding $100 \mu \mathrm{L}$ of stopping solution. Using the ELISA micro-well plate reader, the O. D. value at $450 \mathrm{~nm}$ was recorded and interpreted as the manufacturer's instruction.

\section{Questionnaire Survey}

A structured questionnaire survey was administered to the dog owners regarding information related to dog husbandry and others. The close-ended questions included were age, sex (male, female), breed (exotic, cross, indigenous), housing system (indoor, outdoor), type of dog feed (cooked animal products, raw animal products), the existence of other domestic animals in the household (yes, no), dog owner education level (illiterate, primary, secondary, tertiary), living area/residence (urban, peri-urban), marital status of dog-owning household (single, married, divorced), and presence of rodents in the house. The age of dogs was categorized as a juvenile (6 weeks to 6 months), adolescent ( 6 months to 18 months), adult (18 months to 7 years), and geriatric (greater than 7) years according to Kiflu et $\mathrm{al}^{37}$ and based on owners' information.

\section{Statistical Analysis}

The data from the questionnaire survey and laboratory findings were filled and coded in Microsoft Excel and analyzed using STATA version 14.2. ${ }^{38}$ Chi-square, univariable, and multivariable logistic regression were used to evaluate the relationship between independent (potential risk factors) and outcome variables (seroprevalence). To identify risk factors associated with infection of the Brucella species, a multivariable logistic regression model was used after checking collinearity, and variables with a p-value $<0.25$ in the univariable logistic regression analysis were selected. An adjusted odds ratio with a $95 \%$ confidence interval (ci) was used to express the degree of association. The $95 \%$ confidence level for the subgroup and overall prevalence values were calculated using the exact binomial test. A p-value of $<0.05$ was considered significant.

\section{Ethical Issue}

The purpose of the study was clarified to the owners of the $\operatorname{dog}$ and the members of the family, and then verbal informed consent was obtained from dog owners before blood sample collection. The verbal informed consent from the dog owners was approved by the Research and Ethical Committee of Ambo University. The research team administered the questionnaire face-to-face. The standard 
sample collection protocols were followed to collect blood samples and dogs were handled with best practices of veterinary care. All dogs in the study towns were given an anti-rabies vaccine and anti-parasitic drugs free of charge and service cost.

\section{Results}

\section{Overall Seroprevalence}

The majority of the dogs involved in the study were adults (59.7\%), males (76.1\%), and had outdoor access (69.1\%). Similarly, most of the dogs studied were indigenous (76.6\%) and dog-owning households also had other domestic animals (53.3\%). About $88.6 \%$ of the dogs sampled were from urban areas, while the remaining $11.4 \%$ were from peri-urban areas. The presence of rodents was reported from $46.8 \%$ of dog-owning households.

The overall seroprevalence of Leptospira and Brucella spp infection in dogs was $15.06 \%$ (95\% CI: 11.64-19.04) and $4.16 \%$ (95\% CI: 2.39-6.67), respectively. There was no significant difference in Leptospira spp seropositivity between study towns ( $\mathrm{p}>0.05)$. However, Brucella species seropositivity was significantly different between study towns $(\mathrm{p}<0.05)$ (Table 1$)$.

\section{Risk Factors Leptospira Species Infection}

The results of univariable logistic regression analysis showed that the age of the dog, sex, housing system, breed, type of dog feed, the existence of other domestic animals, dog owner education level, towns, community type, and presence of rodents were not significantly associated with Leptospira seropositivity ( $>00.05$ ) (Table 2). A multivariable logistic regression model was not modeled due to univariable p-values greater than 0.25 .

\section{Brucella Species Infection}

As shown in Table 3, the age of dogs, sex of the dog, housing system, the existence of other domestic animals, dog owner education level, community type, marital status of the head of the household were not significantly associated with Brucella seropositivity $(\mathrm{p}>0.05)$. Sex of the $\mathrm{dog}$, type of $\operatorname{dog}$ feed, existence of other domestic animals, dog owner education level, and the marital status of the household were not fitted to the final model due to their univariable $\mathrm{p}$-value were greater than 0.25. A multivariable logistic regression analysis indicated that the town was an independent predictor of Brucella species infection seropositivity $(\mathrm{p}<0.05)$.

\section{Discussion}

In Ethiopia, there are no recent usable data on the seroprevalence of leptospirosis and brucellosis in dogs, so the current study used data from other countries to compare and contrast. This research report on the infection seroprevalence of the Brucella species in dogs was the first report from Ethiopia. The overall seroprevalence of Leptospira species infection was $15.06 \%$. Our finding on seroprevalence of Leptospira infection was analogous to the seroprevalence in dogs (15.6\%) in Zimbabwe. ${ }^{39}$ Similarly, the seroprevalence of Leptospira infection in the present study was in agreement with the finding of Spangler et $\mathrm{al}^{40}$ who reported $13.1 \%$ seroprevalence in southeastern Appalachia.

Compared to the present findings, the lower seroprevalence of leptospirosis was reported in Malaysia (3.1\%), Thailand (4.4\%), Brazil (7.1\%), and Ethiopia. ${ }^{7,28,41,42}$ On the contrary, the higher seroprevalence of Leptospira infection was reported by Aslantaş et al, ${ }^{43}$ Delaude et $\mathrm{al}^{44}$ and Pratt et $\mathrm{al}^{45}$ from Turkey, Switzerland, and the Caribbean Islands of Saint Kitts with the prevalence of 43.96\% (51/116), 55.7\% (210/377), and 73.2\% (74/101), respectively. These variations in seroprevalence figures recorded by various researchers may be attributable to geographical variance (Leptospira lives longer and persists in hot, humid, and sub-tropical areas), distribution of wild animals, rodents, ${ }^{9}$ types of serological test, sample size, and season of sample collection. Similar to the findings of Meeyam et $\mathrm{al}^{46}$ the present study did not come up with a significant association of canine Leptospira seroprevalence and investigated risk factors like sex and age ( $\mathrm{p}>0.05)$.

In this study, the seroprevalence of the Brucella infection was comparable to the findings of Mosalanezhad et al, ${ }^{47}$ who reported $4.9 \%$ from companion dogs in Ahvaz, Iran. The current finding is also consistent with the $7.5 \%$ seroprevalences of $B$. canis in shelter dogs in Turkey, ${ }^{48} 4.9 \%$ in Mississippi, ${ }^{49}$ and $7.9 \%$ in Japan. ${ }^{50}$

The present study showed that there was a statistically significant difference in Brucella infection among the towns. The seroprevalence of Brucella infection was higher in Gojo and Bako than in Ambo town. In accord with the present findings, a significant difference in the seroprevalence of canine brucellosis concerning the location was also previously reported in southwestern Nigeria. $^{26}$ Although the presence of other domestic animals in the households was not significantly associated 
Table I Overall Seroprevalence of Leptospira and Brucella Species Infection in Dogs in Ambo, Bako, and Gojo Towns

\begin{tabular}{|l|l|l|l|l|l|}
\hline \multirow{2}{*}{ Towns } & \multirow{2}{*}{ No. Tested } & \multicolumn{2}{l|}{ Leptospira Species* } & \multicolumn{2}{l|}{ Brucella Species** } \\
\cline { 2 - 6 } & & No. Positive & Prevalence (95\% Cl) & No. Positive & Prevalence (95\% CI) \\
\hline Ambo & 169 & 25 & $14.79(9.80-21.06)$ & 1 & $0.59(0.01-3.25)$ \\
Gojo & 68 & 12 & $17.65(9.47-28.80)$ & 7 & $10.29(4.24-20.06)$ \\
Bako & 148 & 21 & $14.19(9.0-20.86)$ & 8 & $5.41(2.36-10.37)$ \\
Overall & 385 & 58 & $15.06(11.64-19.04)$ & 16 & $4.16(2.39-6.67)$ \\
\hline
\end{tabular}

Notes: *Chi-square: 0.45 ; p-value: 0.797 . **Chi-square: 12.40; p-value: 0.002

Abbreviations: $\mathrm{No}$, number; $\mathrm{Cl}$, confidence interval.

with seropositivity, the variation in Brucella species ser- Thus, dogs might access Brucella spp infected tissues of oprevalence between towns could be due to extensive breeding of cattle and sheep or abundance and unconthese domestic animals. Therefore, the transmission of trolled movement of dogs in Gojo and Bako towns. disease between dogs and other animals may occur. The spread of brucellosis between the vulnerable host occurs,

Table 2 Univariable Regression Analysis of Potential Risk Factors Associated with the Seropositivity of Dog Leptospira Species Infection in Ambo, Gojo, and Bako Towns

\begin{tabular}{|c|c|c|c|c|c|}
\hline \multirow[t]{2}{*}{ Variables } & \multirow[t]{2}{*}{ Categories } & \multirow[t]{2}{*}{ No. of Tested } & \multirow[t]{2}{*}{ Number of Positive (Prevalence) } & \multicolumn{2}{|l|}{ Univariable } \\
\hline & & & & OR $(95 \% \mathrm{Cl})$ & p-value \\
\hline \multirow[t]{4}{*}{ Age } & Geriatric & 51 & $7(13.73)$ & 1.0 & - \\
\hline & Adult & 230 & $34(14.78)$ & $1.09(0.45-2.62)$ & 0.847 \\
\hline & Juvenile & 27 & $4(14.8 I)$ & $1.09(0.29-4.12)$ & 0.895 \\
\hline & Adolescent & 77 & $13(16.88)$ & $1.28(0.47-3.46)$ & 0.631 \\
\hline \multirow[t]{2}{*}{ Sex } & Female & 92 & $12(13.04)$ & 1.0 & - \\
\hline & Male & 293 & $46(15.70)$ & $1.24(0.63-2.46)$ & 0.535 \\
\hline \multirow[t]{2}{*}{ Housing system } & Outdoor & 266 & $38(14.29)$ & 1.0 & - \\
\hline & Indoor & 119 & $20(16.8 I)$ & $1.21(0.67-2.19)$ & 0.523 \\
\hline \multirow[t]{3}{*}{ Breed } & Exotic & 15 & $2(13.33)$ & 1.0 & - \\
\hline & Indigenous & 296 & $4 \mid(13.85)$ & $1.05(0.23-4.80)$ & 0.955 \\
\hline & Cross & 74 & $15(20.27)$ & $1.65(0.34-8.12)$ & 0.537 \\
\hline \multirow[t]{2}{*}{ Type of dog feed } & Raw meat & 282 & $4 \mid(\mid 4.54)$ & 1.0 & - \\
\hline & Cooked meat & 103 & $17(16.50)$ & $1.16(0.63-2.15)$ & 0.633 \\
\hline \multirow[t]{2}{*}{ Existence of other domestic animals } & No & 181 & $24(13.26)$ & 1.0 & - \\
\hline & Yes & 204 & $34(16.67)$ & $1.30(0.74-2.30)$ & 0.352 \\
\hline \multirow[t]{4}{*}{ Dog owner education level } & Secondary & 125 & $15(12.00)$ & 1.0 & - \\
\hline & Illiterate & 47 & $7(14.89)$ & $1.28(0.49-3.38)$ & 0.613 \\
\hline & Primary & 98 & $16(16.33)$ & $1.43(0.67-3.06)$ & 0.356 \\
\hline & Tertiary & 115 & $20(17.39)$ & $1.54(0.75-3.18)$ & 0.239 \\
\hline \multirow[t]{3}{*}{ Towns } & Bako & 148 & $21(14.19)$ & 1.0 & - \\
\hline & Ambo & 169 & $25(14.79)$ & $1.05(0.56-1.97)$ & 0.879 \\
\hline & Gojo & 68 & $12(17.65)$ & $1.30(0.60-2.82)$ & 0.513 \\
\hline \multirow[t]{2}{*}{ Community type } & Urban & 341 & $48(14.08)$ & 1.0 & \\
\hline & Peri-urban & 44 & $10(22.73)$ & $1.80(0.83-3.87)$ & 0.135 \\
\hline \multirow[t]{2}{*}{ Presence of rodents } & No & 205 & $29(14.15)$ & 1.0 & - \\
\hline & Yes & 180 & $29(16.11)$ & $1.17(0.67-2.04)$ & 0.591 \\
\hline
\end{tabular}


Table 3 Univariable and Multivariable Logistic Regression Analysis of Potential Risk Factors Associated with the Seropositivity of Dog Brucella Species Infection in Ambo, Gojo, and Bako Towns

\begin{tabular}{|c|c|c|c|c|c|c|c|}
\hline \multirow[t]{2}{*}{ Variables } & \multirow[t]{2}{*}{ Categories } & \multirow{2}{*}{$\begin{array}{l}\text { No. of } \\
\text { Tested }\end{array}$} & \multirow{2}{*}{$\begin{array}{l}\text { Number of Positive } \\
\text { (Prevalence) }\end{array}$} & \multicolumn{2}{|l|}{ Univariable } & \multicolumn{2}{|l|}{ Multivariable } \\
\hline & & & & OR $(95 \% \mathrm{Cl})$ & p-value & OR $(95 \% \mathrm{Cl})$ & p-value \\
\hline Age & $\begin{array}{l}\text { Adolescent } \\
\text { Juvenile } \\
\text { Geriatric } \\
\text { Adult }\end{array}$ & $\begin{array}{l}77 \\
27 \\
51 \\
230\end{array}$ & $\begin{array}{l}\text { I }(1.30) \\
\text { I }(3.70) \\
2(3.92) \\
\text { I2 (5.22) }\end{array}$ & $\begin{array}{l}1.0 \\
2.92(0.18-48.42) \\
3.10(0.27-35.16) \\
4.18(0.53-32.71)\end{array}$ & $\begin{array}{l}- \\
0.454 \\
0.361 \\
0.173\end{array}$ & $\begin{array}{l}1.0 \\
2.02(0.12-35.50) \\
2.27(0.19-26.77) \\
5.70(0.69-47.23)\end{array}$ & $\begin{array}{l}- \\
0.628 \\
0.516 \\
0.106\end{array}$ \\
\hline Sex & $\begin{array}{l}\text { Male } \\
\text { Female }\end{array}$ & $\begin{array}{l}293 \\
92\end{array}$ & $\begin{array}{l}\text { II (3.75) } \\
5(5.43)\end{array}$ & $\begin{array}{l}1.0 \\
1.47(0.50-4.36)\end{array}$ & $\begin{array}{l}- \\
0.484\end{array}$ & & \\
\hline Housing system & $\begin{array}{l}\text { Indoor } \\
\text { Outdoor }\end{array}$ & $\begin{array}{l}119 \\
266\end{array}$ & $\begin{array}{l}2(1.68) \\
14(5.26)\end{array}$ & $\begin{array}{l}1.0 \\
3.25(0.73-14.53)\end{array}$ & $\begin{array}{l}- \\
0.123\end{array}$ & $\begin{array}{l}1.0 \\
2.08(0.44-9.91)\end{array}$ & $\begin{array}{l}- \\
0.356\end{array}$ \\
\hline Type of dog feed & $\begin{array}{l}\text { Cooked meat } \\
\text { Raw meat }\end{array}$ & $\begin{array}{l}103 \\
282\end{array}$ & $\begin{array}{l}2(1.94) \\
14(4.96)\end{array}$ & $\begin{array}{l}1.0 \\
2.64(0.59-11.81)\end{array}$ & $\begin{array}{l}- \\
0.205\end{array}$ & $\begin{array}{l}1.0 \\
3.59(0.74-17.29)\end{array}$ & $\begin{array}{l}- \\
0.111\end{array}$ \\
\hline $\begin{array}{l}\text { Existence of other } \\
\text { domestic animals }\end{array}$ & $\begin{array}{l}\text { No } \\
\text { Yes }\end{array}$ & $\begin{array}{l}181 \\
204\end{array}$ & $\begin{array}{l}6(3.31) \\
10(4.90)\end{array}$ & $\begin{array}{l}1.0 \\
1.50(0.53-4.22)\end{array}$ & $\begin{array}{l}- \\
0.439\end{array}$ & & \\
\hline Dog owner education level & $\begin{array}{l}\text { Illiterate } \\
\text { Primary } \\
\text { Secondary } \\
\text { Tertiary }\end{array}$ & $\begin{array}{l}47 \\
98 \\
125 \\
115\end{array}$ & $\begin{array}{l}1 \text { ( }(2.13) \\
3(3.06) \\
5(4.00) \\
7(6.09)\end{array}$ & $\begin{array}{l}1.0 \\
1.45(0.15-14.35) \\
1.92(0.22-16.85) \\
2.98(0.36-24.93)\end{array}$ & $\begin{array}{l}- \\
0.749 \\
0.557 \\
0.313\end{array}$ & & \\
\hline Towns & $\begin{array}{l}\text { Ambo } \\
\text { Bako } \\
\text { Gojo }\end{array}$ & $\begin{array}{l}169 \\
148 \\
68\end{array}$ & $\begin{array}{l}I(0.59) \\
8(5.4 I) \\
7(10.29)\end{array}$ & $\begin{array}{l}1.0 \\
9.60(1.19-77.69) \\
19.27(2.32-159.92)\end{array}$ & $\begin{array}{l}- \\
0.034 \\
0.006\end{array}$ & $\begin{array}{l}1.0 \\
7.99(0.96-66.37) \\
11.72(1.17-117.54)\end{array}$ & $\begin{array}{l}- \\
0.054 \\
0.036\end{array}$ \\
\hline Community Type & $\begin{array}{l}\text { Urban } \\
\text { Peri-urban }\end{array}$ & $\begin{array}{l}341 \\
44\end{array}$ & $\begin{array}{l}10(2.93) \\
6(13.64)\end{array}$ & $\begin{array}{l}1.0 \\
5.22(1.80-15.18)\end{array}$ & $\begin{array}{l}- \\
0.002\end{array}$ & $\begin{array}{l}1.0 \\
2.56(0.68-9.68)\end{array}$ & $\begin{array}{l}- \\
0.165\end{array}$ \\
\hline $\begin{array}{l}\text { The marital status of the } \\
\text { household }\end{array}$ & $\begin{array}{l}\text { Divorced } \\
\text { Married } \\
\text { Single }\end{array}$ & $\begin{array}{l}25 \\
343 \\
17\end{array}$ & $\begin{array}{l}\text { I (4.00) } \\
\text { I4 (4.08) } \\
\text { I (5.88) }\end{array}$ & $\begin{array}{l}1.0 \\
1.02(0.13-8.10) \\
1.50(0.08-25.75)\end{array}$ & $\begin{array}{l}- \\
0.984 \\
0.780\end{array}$ & & \\
\hline
\end{tabular}

mainly direct contact with an affected animal after abortion and sharing a home. ${ }^{51}$

In the current research, when other domestic animals were present in the household, the seropositivity of dogs to Leptospira and Brucella infections was moderately high as compared to the absence of other domestic animals in the household owning dogs.

The seroprevalence of Brucella and Leptospira infections was higher in those dogs fed raw meat as compared to dogs fed cooked meat. This distinction is possible because cooking animal tissues or meat could kill microorganisms.

The seropositivity of Brucella infection was relatively higher in female than in male dogs and peri-urban dogs than urban dogs. Similarly, the seroprevalence of Brucella species infection in adult and geriatric dogs was 4.18 and 3.10 times higher, respectively, than the seroprevalence in young dogs. Dogs held in the outdoor housing system
(5.26\%) had a slightly higher seroprevalence of Brucella species infection than indoor kept dogs (1.68\%). However, the statistical analysis revealed that there were no significant differences among categories of these variables concerning Brucella species infection.

Leptospirosis and brucellosis are still a serious public health problem worldwide, and a dog could serve as a source of infection for other animals and humans. Ethiopia is an agrarian country with huge untapped livestock resources dominated by traditional husbandry and owned by poor farmers. In Africa, Ethiopia ranks second only to Nigeria in the health burden of zoonotic diseases and stands in the first place as a hot spot of leptospirosis in the world. ${ }^{52}$

The high humidity and rainfall in the studied towns coupled with the fact that infected dogs remain chronic carriers and shedders of Leptospira through their urine, ${ }^{42}$ it is likely that the environment of the towns is 
contaminated, posing a risk of infection to other animals and humans.

The present study showed the status of Brucella and Leptospira infections and their associated factors in dogs in the study area. In Ethiopia, dog ownership is common, and humans live in close contact with dogs and other animals. In addition, there is no vaccination and control program for brucellosis and leptospirosis. Brucella and Leptospira circulate between dogs, other animals, and human beings. Both diseases reduce the productivity of livestock and induce medical problems in humans. Although Ethiopia mainly depends on livestock production, information that supports the prevention and control of these diseases is not well accessible. Therefore, the present findings will have an invaluable input to prevent and control brucellosis and leptospirosis in Ethiopia.

Despite the important findings, the main limitation of the current study was the failure to identify the serovars of Leptospira and species of Brucella due to the nature of the diagnostic kits used. The Brucella ELISA kit in the current study uses a multi-species conjugate, which recognizes mammalian antibodies and therefore should work on dog sera. However, the kit is not validated for canine sera. It does not detect also Brucella canis hence the results might be an underestimate. Furthermore, the association of some significant risk factors like abortion, stillbirth, neonatal death, retained placenta with Brucella seropositivity were not assessed. The association of rainfall with Leptospira seropositivity was not also investigated. Those households not willing to participate in the study might not be evenly distributed in all sampling areas and door-to-door sampling was done once the index case was identified. These might entail some bias. Such studies could have given more data into the epidemiology of brucellosis and leptospirosis in the studied dogs. Therefore, the findings of this study should be observed in light of these limitations.

\section{Conclusions}

In conclusion, a relatively high seroprevalence of Leptospira and moderate Brucella spp infections were found in dogs of the West Shewa Zone. Consequently, the risk of contracting these infections is higher among humans and other domestic animals. Leptospira and Brucella spp infections might constitute an under-recognized threat to public health and animal welfare. The town is the predictor of Brucella spp seropositivity. None of the considered variables were independent predictors of Leptospira spp seropositivity. Further research is encouraged on the detection of Leptospira serovar and Brucella species circulating in dogs. Finally, comprehensive knowledge of the epidemiology of these infections is valuable input for veterinarians, health care professionals, and policy-makers to manage these infections.

\section{Acknowledgments}

We would like to thank Ambo University and the Italian National Reference Centre for Toxoplasmosis at the Istituto Zooprofilattico Sperimentale della Sicilia A. Mirri, Italy for their financial support. We would also like to thank the dog owners and veterinarians for their cooperation during the field study. The National Animal Health Diagnostic Center (NAHDIC) at Sebeta is highly acknowledged for allowing the laboratory facilities.

\section{Author Contributions}

All authors made a significant contribution to the work reported either in the conception of the study, execution, acquisition of data, analysis, and interpretation or in all these areas. Moreover, all authors took part in revising or critically reviewing the article; gave final approval of the version to be published; have agreed on the journal to which the article has been submitted; and agree to be accountable for all aspects of the work.

\section{Funding}

This work was supported by Ambo University and the Italian National Reference Centre for Toxoplasmosis at the Istituto Zooprofilattico Sperimentale della Sicilia A. Mirri, Italy (grant No. RF 2007/RC).

\section{Disclosure}

The authors declare that there are no conflicts of interest regarding the publication of this paper.

\section{References}

1. Cutler S, Whatmore A, Commander N. Brucellosis-new aspects of an old disease. J Appl Microbiol. 2005;98(6):1270-1281. doi:10.1111/ j.1365-2672.2005.02622.x

2. Heinemann MB, Garcia JF, Nunes CM, et al. Detection and differentiation of Leptospira spp. serovars in bovine semen by polymerase chain reaction and restriction fragment length polymorphism. Vet Microbiol. 2000;73(4):261-267. doi:10.1016/s0378-1135(00)00150-4

3. Ocholi R, Kwaga J, Ajogi I, Bale J. Abortion due to Brucella abortus in sheep in Nigeria. Rev Sci Tech off Int Epiz. 2005;24(3):973. doi:10.20506/rst.24.3.1627

4. McVey DS, Kennedy M, Chengappa MM. Veterinary Microbiology. 3rd ed. USA: John Wiley \& Sons, Inc.; 2013. 
5. Bharti AR, Nally JE, Ricaldi JN, et al. Leptospirosis: a zoonotic disease of global importance. Lancet Infect Dis. 2003;3(12):757771. doi:10.1016/s1473-3099(03)00830-2

6. Costa F, Hagan JE, Calcagno J, et al. Global morbidity and mortality of leptospirosis: a systematic review. PLoS Negl Trop Dis. 2015;9(9): e0003898. doi:10.1371/journal.pntd.0003898

7. Lavinsky MO, Abou Said R, Strenzel GMR, Langoni H. Seroprevalence of anti-Leptospira spp. antibodies in dogs in Bahia, Brazil. Prev Vet Med. 2012;106(1):79-84. doi:10.1016/j. prevetmed.2012.03.015

8. Levett PN. Leptospirosis. Clin Microbiol Rev. 2001;14(2):296. doi:10.1128/CMR.14.2.296-326.2001

9. de Vries SG, Visser BJ, Nagel IM, Goris MGA, Hartskeerl RA, Grobusch MP. Leptospirosis in Sub-Saharan Africa: a systematic review. Int $J$ Infect Dis. 2014;28:47-64. doi:10.1016/j. ijid.2014.06.013

10. Markey B, Leonard F, Archambault M, Cullinane A, Maguire D. Clinical Veterinary Microbiology e-Book. Elsevier Health Sciences; 2013.

11. López M, Vila A, Rodón J, Roura X. Leptospira seroprevalence in owned dogs from Spain. Heliyon. 2019;5(8):e02373. doi:10.1016/j. heliyon.2019.e02373

12. Schuller S, Arent Z, Gilmore C, Nally J. Prevalence of antileptospiral serum antibodies in dogs in Ireland. Vet Rec. 2015;177(5):126. doi:10.1136/vr.102916

13. Lunn KF Leptospirosis in dogs - generalized conditions - veterinary manual; 2020. Available from: https://www.msdvetmanual.com/gen eralized-conditions/leptospirosis/leptospirosis-in-dogs\#: :text=Dogs $\% 20$ are $\% 20$ the $\% 20$ primary $\% 20$ host,in $\% 20$ tissues $\% 2$ C $\% 20$ blood $\%$ 20or\%20urine. Accessed August 18, 2020.

14. Alton GD, Berke O, Reid-Smith R, Ojkic D, Prescott JF. Increase in seroprevalence of canine leptospirosis and its risk factors, Ontario 1998-2006. Can J Vet Res. 2009;73(3):167-175.

15. Ramamoorthy S, Woldemeskel M, Ligett A, Snider R, Cobb R, Rajeev S. Brucella suis infection in dogs, Georgia, USA. Emerg Infect Dis. 2011;17(12):2386-2387. doi:10.3201/eid1712.111127

16. Akhvlediani T, Bautista CT, Garuchava N, et al. Epidemiological and clinical features of brucellosis in the country of Georgia. PLoS One. 2017;12(1):e0170376. doi:10.1371/journal.pone.0170376

17. Pappas G, Papadimitriou P, Akritidis N, Christou L, Tsianos E. The new global map of human brucellosis. Lancet Infect Dis. 2006;6:9199. doi:10.1016/S1473-3099(06)70382-6

18. Seleem MN, Boyle SM, Sriranganathan N. Brucellosis: a re-emerging zoonosis. Vet Microbiol. 2010;140(3-4):392-398. doi:10.1016/j. vetmic.2009.06.021

19. Whatmore AM. Current understanding of the genetic diversity of Brucella, an expanding genus of zoonotic pathogens. Infect Genet Evol. 2009;9(6):1168-1184. doi:10.1016/j.meegid.2009.07.001

20. Hensel ME, Negron M, Arenas-Gamboa AM. Brucellosis in dogs and public health risk. Emerg Infect Dis. 2018;24(8):1401-1406. doi:10.3201/eid2408.171171

21. Nomura A, Imaoka K, Imanishi $\mathrm{H}$, et al. Human Brucella canis infections diagnosed by blood culture. Emerg Infect Dis. 2010;16 (7):1183-1185. doi:10.3201/eid1607.090209

22. Lopes LB, Nicolino R, Haddad JPA. Brucellosis-risk factors and prevalence: a review. Open Vet J. 2010;4(1):72-84. doi:10.2174/ 1874318801004010072

23. Pujol M, Castillo F, Alvarez C, et al. Variability in the response of canine and human dendritic cells stimulated with Brucella canis. Vet Res. 2017;48(1):72. doi:10.1186/s13567-017-0476-8

24. Sayan M, Erdenlig S, Stack J, et al. A serological diagnostic survey for Brucella canis infection in Turkish patients with Brucellosis-like symptoms. Jpn J Infect Dis. 2011;64(6):516-519.

25. Lucero N, Corazza R, Almuzara M, et al. Human Brucella canis outbreak linked to infection in dogs. Epidemiol Infect. 2010;138 (2):280-285. doi:10.1017/S0950268809990525
26. Ayoola MC, Ogugua AJ, Akinseye VO, et al. Sero-epidemiological survey and risk factors associated with brucellosis in dogs in southwestern Nigeria. Pan Afr Med J. 2016;23(1):1-8. doi:10.11604/ pamj.2016.23.1.8442

27. Wanke M. Canine brucellosis. Anim Reprod Sci. 2004;82:195-207. doi:10.1016/j.anireprosci.2004.05.005

28. Moch RW, Ebner EE, Barsoum LS, Botros BA. Leptospirosis in Ethiopia: a serological survey in domestic and wild animals. $J$ Trop Med Hyg. 1975;78(2):38-42.

29. Yimer E, Koopman S, Messele T, et al. Human leptospirosis, in Ethiopia: a pilot study in Wonji. Ethiop J Health Dev. 2004;18 (1):01-06.

30. Tsegay K, Potts A, Aklilu N, Lötter C, Gummow B. Circulating serovars of Leptospira in cart horses of central and southern Ethiopia and associated risk factors. Prev Vet Med. 2016;125:106115. doi:10.1016/j.prevetmed.2016.01.009

31. Megersa B, Biffa D, Niguse F, Rufael T, Asmare K, Skjerve E. Cattle brucellosis in traditional livestock husbandry practice in Southern and Eastern Ethiopia, and its zoonotic implication. Acta Vet Scand. 2011;53(1):24. doi:10.1186/1751-0147-53-24

32. Geresu MA, Ameni G, Tuli G, Arenas A, Kassa GM. Seropositivity and risk factors for Brucella in dairy cows in Asella and Bishoftu towns, Oromia Regional State, Ethiopia. Afr J Microbiol Res. 2016;10(7):203-213. doi:10.5897/AJMR2015.7707

33. Edao BM, Ameni G, Assefa Z, Berg S, Whatmore AM, Wood JL. Brucellosis in ruminants and pastoralists in Borena, Southern Ethiopia. PLoS Negl Trop Dis. 2020;14(7):e0008461. doi:10.1371/ journal.pntd.0008461

34. CSA. Population and Housing Census of Ethiopia; 2007.

35. Chappuis G. Neonatal immunity and immunisation in early age: lessons from veterinary medicine. Vaccine. 1998;16(14-15):14681472. doi:10.1016/S0264-410X(98)00110-8

36. Thrusfield M. Veterinary Epidemiology; Describing Disease Occurrence. 3rd ed. Blackwell Publishing; 2005.

37. Kiflu B, Alemayehu H, Abdurahaman M, Negash Y, Eguale T. Salmonella serotypes and their antimicrobial susceptibility in apparently healthy dogs in Addis Ababa, Ethiopia. BMC Vet Res. 2017;13 (1):134. doi:10.1186/s12917-017-1055-y

38. Statistical Software [computer program]. Version 14.2. USA: StataCorp; 2018.

39. Dhliwayo S, Matope G, Dutlow K, Pfukenyi DM, Marabini L. Seroprevalence of leptospirosis in dogs in urban Harare and selected rural communities in Zimbabwe. Onderstepoort J Vet Res. 2012;79 (1):1-6. doi:10.4102/ojvr.v79i1.447

40. Spangler D, Kish D, Beigel B, et al. Leptospiral shedding and seropositivity in shelter dogs in the Cumberland Gap Region of Southeastern Appalachia. PLoS One. 2020;15(1):e0228038. doi:10.1371/journal.pone. 0228038

41. Lau S, Wong J, Khor K, et al. Seroprevalence of leptospirosis in working dogs. Top Companion Anim Med. 2017;32(4):121-125. doi:10.1053/j.tcam.2017.12.001

42. Altheimer K, Jongwattanapisan $\mathrm{P}$, Luengyosluechakul $\mathrm{S}$, et al. Leptospira infection and shedding in dogs in Thailand. BMC Vet Res. 2020;16(1):1-13. doi:10.1186/s12917-020-2230-0

43. Aslantaş Ö, Özdemir V, Kiliç S, Babür C. Seroepidemiology of leptospirosis, toxoplasmosis, and leishmaniosis among dogs in Ankara, Turkey. Vet Parasitol. 2005;129(3-4):187-191. doi:10.1016/j.vetpar.2004.11.037

44. Delaude A, Rodriguez-Campos S, Dreyfus A, et al. Canine leptospirosis in Switzerland-A prospective cross-sectional study examining seroprevalence, risk factors and urinary shedding of pathogenic leptospires. Prev Vet Med. 2017;141:48-60. doi:10.1016/j. prevetmed.2017.04.008

45. Pratt N, Conan A, Rajeev S. Leptospira seroprevalence in domestic dogs and cats on the Caribbean Island of Saint Kitts. Vet Med Int. 2017;2017:1-6. doi:10.1155/2017/5904757 
46. Meeyam T, Tablerk P, Petchanok B, Pichpol D, Padungtod P. Seroprevalence and risk factors associated with leptospirosis in dogs. Southeast Asian J Trop Med Public Health. 2006;37(1):148.

47. Mosalanezhad B, Ghorbanpour NM, Avizeh R, Mohammadian N. A serological survey on Brucella canis in companion dogs in Ahvaz. Iran J Vet Res. 2009;10(4):383-386.

48. Öncel T, Akan M, Sareyyüpoğlu B, Tel OY, Çiftci A. Seroprevalence of Brucella canis infection of dogs in two provinces in Turkey. Turk J Vet Anim Sci. 2005;29(3):779-783.

49. Hubbard K, Wang M, Smith DR. Seroprevalence of brucellosis in Mississippi shelter dogs. Prev Vet Med. 2018;159:82-86. doi:10.1016/j.prevetmed.2018.09.002
50. Kei N, Shingo S, Hidenori K, Soichi M. Seroepidemiological survey of Brucella canis infection in dogs in Japan. Jpn J Vet Res. 2020;68 (2):129-132. doi:10.14943/jjvr.68.2.129

51. Upadhyay A, Singh P, Nagpal A. Epidemiology of brucellosis in India: a review. Pantnagar J Res. 2019;17(3):199-205.

52. Grace D, Mutua F, Ochungo P, et al. Mapping of poverty and likely zoonoses hotspots. Report to the UK Department for International Development; 2012.

\section{Publish your work in this journal}

Veterinary Medicine: Research and Reports is an international, peerreviewed, open access journal publishing original research, case reports, editorials, reviews and commentaries on all areas of veterinary medicine. The manuscript management system is completely online and includes a very quick and fair peer-review system. Visit http://www.dovepress.com/testimonials.php to read real quotes from published authors. 